\title{
Karakter Peduli Sosial: Komparasi Modul Elektronik dan Paper Modul Kearifan Lokal Ngubat Padi di Sekolah Dasar
}

\author{
Asrial $^{1)}$, Syahrial $^{2)}$, Dwi Agus Kurniawan ${ }^{3)}$, Juwita Saputri ${ }^{4)}$ \\ ${ }^{1)}$ Fakultas Keguruan dan Ilmu Pendidikan, Universitas Jambi \\ ${ }^{1)}$ email: porigih@gmail.com \\ ${ }^{2)}$ Fakultas Keguruan dan Ilmu Pendidikan, Universitas Jambi \\ ${ }^{2)}$ email: syahrial.karea@gmail.com \\ ${ }^{3)}$ Fakultas Keguruan dan Ilmu Pendidikan, Universitas Jambi \\ ${ }^{3)}$ email: $₫$ dwiagus.k@unja.ac.id \\ ${ }^{4)}$ Fakultas Keguruan dan Ilmu Pendidikan, Universitas Jambi \\ 4) email: juwitasaputri33@gmail.com
}

\begin{abstract}
Abstrak
Tujuan penelitian ini adalah untuk membandingkan penerapan modul cetak dan modul elektronik untuk melihat indikator karakter peduli sosial. Jenis penelitian ini adalah penelitian kuantitatif. Penelitian ini melibatkan dua variabel yaitu pembelajaran bahan ajar di kelas dengan jumlah sampel 57 siswa. Analisis data menggunakan statistik deskriptif dan inferensial. Karakter peduli sosial siswa dapat dilihat pada penerapan modul elektronik dan modul cetak. Hasilnya, dari kedua bahan ajar tersebut, karakter peduli sosial siswa SD 64/I Muara Bulian dominan dalam kategori baik, sedangkan karakter peduli sosial siswa dengan penerapan modul cetak dominan sudah cukup.
\end{abstract}

Kata kunci: karakter peduli sosial, modul elektronik, modul cetak, kearifan lokal

\section{Abstrack}

The purpose of this study was to compare the application of the print module and the electronic module to see the indicators of the character of social care. This type of research is quantitative research. This study involved two variables, namely learning teaching materials in class with a sample size of 47 students. Data analysis used descriptive and inferential statistics. The character of students' social care can be seen in the application of the electronic module and the print module. The result, from the two teaching materials, the social care character of SD 64/I Muara Bulian students was dominant in the good category, while the social care character of students with the application of the dominant print module was sufficient.

Keywords: social care character, printed module, electronic module, local wisdom

\section{PENDAHULUAN}

Indonesia merupakan negara dengan banyak kebudayaan atau kearifan lokal serta adat istiadat yang mengajarkan banyak nilai moral dan kehidupan untuk masyarakatnya. Nilai yang ada pada kearifan lokal memudahkan nilai yang ada diintegrasikan pada semua bidang kehidupan, baik ekonomi maupun pendidikan (Utari \& Degeng, 2017; Nuraini, 2019; Eko, 2020). Pengintegrasian kearifan lokal pada bidang pendidikan dapat dilakukan dengan pengoptimalisasi pembelajaran yang ada di sekolah (Qodariah \& Armiyati, 2013; Ghufron, 2017; Winarni, et.al, 2018). Nilai kearifan lokal yang ada pada suatu wilayah dapat digunakan sebagai pembelajaran pada anak-anak usia sekolah (Wariin, 2014; Ramdani, 2018; Naryatmojo, 2019). Kearifan lokal yang dapat memberikan banyak niali karakter memang perlu diintegrasikan pada pembelajaran di sekolah terkhusus untuk pembelajaran di sekolah dasar.

Kearifan lokal yang tersebar diseluruh Indonesia banyak terdapat pada pembelajaran di sekolah dasar sebagai bentuk mengenalkan budaya bangsa. Kearifan lokal dianggap sebagai kekayaan bangsa dimana pembelajaran yang diberikan memberikan nilai kebaikan bagi mereka (Kurniawan, 2013; Yulianti, Djatmika \& Santoso, 2017; Sopacua, Fadli \& Rochmat, 2020). Nilai karakter merupakan hal penting dalam proses pembelajaran terutama pada tema mata pelajaran, hal tersebut merupakan perubahan yang perlu dioptimalkan (Saputro \& Soeharto, 2015; Kazu \& Is, 2018; Setiawan \& Sulistiani, 2019). Berdasarkan rekam jejak 
digital yang ada banyak kearifan lokal yang dapat memberikan pembelajaran dengan nilai karakter pada peserta didik pada bidang pendidikan (Mumpuni, 2013; Basri, 2017; Sahin \& Is Guzel, 2018). Salah satunya pada kearifan lokal yang ada di Provinsi Jambi yaitu Ngubat Padi dari Kabupaten Tebo yang dapat diintgrasikan dengan banyak nilai-nilai karakter seperti cinta damai, toleransi, peduli lingkungan, rasa ingin tahu, gemar membaca dan tanggungjawab.

Kearifan lokal Ngubat Padi juga dapat diintegrasikan pada karakter peduli sosial yang sesuai dengan materi yang ada pada pembelajaran. Karakter peduli sosial merupakan suatu perilaku untuk menyesuaikan diri dengan situasi sosial dengan adanya interaksi sosial setiap individu (Wuryandani, Mahftuh \& Budimansyah, 2014; Davidson, et.al, 2016; Fauzi, Zainuddin \& Atok, 2018). Interaksi sosial antar individu terjadi hubungan saling mempengaruhi diantara individu yang satu dengan yang lain, terjadi hubungan timbal balik yang turut mempengaruhi pola perilaku masingmasing individu sebagai anggota masyarakat (Busyaeri \& Muharom, 2016; Muhamadi \& Hasanah, 2019; Kurniawan, Novianti \& Parhati, 2020). Karakter peduli sosial akan mengukur kepedulian seseorang baik itu peserta didik kepada lingkungan sosial (Murniyeti, Engkizar \& Anwar, 2016; Lestari \& Rohani, 2017; Rahmawati \& Dewi, 2020). Maka dari itu perlu diterapkan nilai-nilai karakter pada diri peserta didik pada pembelajaran di kelas.

Penerapan karakter peduli sosial pada pembelajaran di sekolah menjadi tantangan baru bagi seorang pendidik atau guru. Keintegrasian nilai peduli sosial pada pembelajaran sebaiknya dilakukan dengan mengembangkan instrumen pembelajaran (Wentas, 2019; Damayanti, 2020; Roessingh, 2020). Pengembangan instrumen pembelajaran yang akan dilakukan guru penting memperhatikan kemampuan siswa serta keadaan lingkungan siswa. Banyak guru belum mengintegrasikan kearifan lokal dalam pembelajaran dengan alasan belum mengenal kearifan lokal di lingkungannya, sehingga sulit dikembangkan bahan ajar yang berbasis kearifan lokal (Ufie, 2014; Satriawan \& Rosmiati, 2017; Shufa, 2018). Pengembangan bahan ajar berbasis kearifan lokal menjadi bahan ajar yang kontekstual untuk meningkatkan pemahaman konsep kearifan lokal, bahan ajar ini dapat berbasis elektronik maupun cetak (Eliza, 2017; Aulia \& Wuryandani, 2019; Deane, 2020).

Bahan ajar yang digunakan pada proses pembelajaran befungsi untuk mempermudah penyampaian materi yang akan diberikan guru. Berbagai kemudahan diharapkan dapat meningkatkan kualitas pembelajaran untuk mencapai tujuan pembelajaran yang menyesuaikan keadaan perkembangan teknologi saat ini (Seso, Laksana \& Dua, 2019; Hinojoso, et.al, 2020; Lawe, et.al, 2021). Contoh bahan ajar berbasis elektronik diantaranya Audio Cassette, siaran radio, slide, filmstrips, film, video pembelajaran, siaran televisi, video interaktif, tutorial, dam multi media (Suwatra \& Suyatna, 2015; Noviyanita, 2019; Puspitasari, 2019). Pembelajaran dengan bahan ajar berbasis elektronik tentunya memiliki kelemahan pada penerapannya, dari sarana dan prasarana yang kurang memadai serta keahlian guru dalam mengoperasikannya (Yuliati, 2013; Pradana, Khoirunnisa \& Yulita, 2020; Nuryati, Anggoro \& Putra, 2021). Namun disamping itu banyak kelebihan yang didapatkan dengan menerapkan bahan ajar elektronik diantaranya lebih praktis dan efesien dengan materi dan latihan soal yang bervarian tidak hanya teks tetapi terdapat gambar serta video (Sokolova, Rostovtseva \& Wasilewski, 2015; Abdurahimovna, 2020; Ambarita, 2021). Penerapan bahan ajar elektronik ini guna untuk meningkatkan aktivitas dan hasil belajar pada siswa tanpa mengesampikan bahan ajar cetak.

Penerapan bahan ajar cetak merupakan pembelajaran dimana bahan untuk ajar berupa lembaran buku kertas yang dapat dipegang dan dibaca secara langsung (Zuriah, Sunaryo \& Yusuf, 2016; Cahyadi, 2019; Skoufaki \& Petrić, 2021). Contoh bahan ajar cetak diantaranya buku famlet, panduan belajar siswa, bahan tutorial, buku kerja siswa, peta, charts, foto dari majalah atau koran, dan sebagainya (Farida \& Yani, 2013; Lim, et.al, 2016; Dyrvold \& Bergvall, 2018). Kelebihan penarapan bahan ajar cetak adalah tidak diperlukannya alat yang khusus dan mahal, bahan ajar cetak lebih relatif murah pembelian serta pengirimannya 
(Kurniawan \& Miftah, 2015; Lioufas, et.al, 2016; Amelia, 2018). Disamping kelebihan diterapkannya bahan ajar cetak, juga memiliki kekurangan yaitu dari segi materi yang memiliki keterbatasan, selain itu bahan ajar ini mudah sekali rusak (Muqodus, et.al, 2015; Afriandi, Elmunsyah \& Putranto, 2020; Tarfaoui, et.al, 2020). Berdasarkan rekan jejak digital yang ada banyak guru telah menerapkan bahan ajar baik itu elektronik maupun cetak dengan keadaan sarana prasarana sesuai dengan lingkungan pendidikan mereka masing-masing.

Tujuan penelitian ini adalah untuk mengetahui tingkat karakter peduli sosial di kelas dengan menggunakan modul cetak dan elektronik materi Ngubat Padi Tema 8 Subtema 3 Pembelajaran 1 untuk jangka pendek. Adapun pertanyaan penelitian sebagai berikut:

1. Bagaimana respon siswa terhadap penggunaan modul berbasis kearifan lokal Ngubat Padi?

2. Bagaimana respon siswa terhadap penerapan modul cetak materi Tema 8 Subtema 3 Pembelajaran 1?

3. Bagaimana tingkat karakter peduli sosial peserta didik dengan penerapan modul cetak dan modul elektronik berbasis kearifan lokal pada?

\section{METODOLOGI}

Penelitian ini menggunakan pendekatan kuantitatif dan kualitatif (Mixed Method) adalah apabila peneliti memiliki pertanyaan yang perlu diuji dari segi jenis penelitian dan prosesnya, serta menyangkut kombinasi antara metode kuantitatif dan kualitatif dalam satu penelitian (Senjaya, 2018; Hermawan, 2019; Sugiono, 2019). Dengan menggunakan desain penelitian Explanatory Sequential Design yaitu desain yang menyiratkan pengumpulan dan analisis kuantitatif sebagai data pokok dan kemudian kualitatif data dalam dua fase berturut-turut dalam satu studi (Creswell, 2013; Li, et.al, 2015; Wipulanusat, dkk, 2020).

Instrumen penelitian menggunakan angket dan wawancara. Angket merupakan alat pengumpulan data yang dapat dilakukan dengan menyebarkan serangkaian pertanyaan dan pernyataan tertulis kepada narasumber dari anggota sampel penelitian (Maryuliana, Subroto \& Haviana, 2016; Sudibyo, Jatmiko \& Widodo, 2017; Gunawan, dkk, 2019). Angket yang digunakan berupa angket kedua indikator karakter peduli sosial yaitu respon penerapan modul cetak dan modul elektronik untuk melihat karakter peduli sosial. Dengan jumlah soal valid masing-masing 20 butir soal. Sedangkan untuk reliabilitas dihitung menggunakan rumus cronbach alpha. Setelah instrument diuji coba dan dianalisis reliabilitasnya, diperoleh koefisien reliabilitas angket penerapan modul cetak pada indikator saling berbagi sebesar 0,780 dan untuk modul elektronik pada indikator saling bekerjasama 0,720 sehingga dapat disimpulkan bahwa instrument reliabel. Pada angket menggunakan kategori skala Likert dengan jenis skalanya sangat setuju (SS), setuju (S), tidak yakin (N), tidak setuju (TS), dan sangat tidak setuju (STS). Pada setiap soal yang bernilai positif dalam instrumen yang memiliki nilai: SS $=5, \mathrm{~S}=4, \mathrm{~N}=3$, TS $=2$, dan $\mathrm{STS}=1$. Skor dibalik untuk nilai pada item soal negatif. Angket yang diberikan kepada responden digunakan untuk mengukur data kuantitatif. Berikut adalah kisi-kisi angket penelitian.

\section{TABEL 1. Kisi-kisi angket respon siswa di kelas Modul Elektronik dan Cetak}

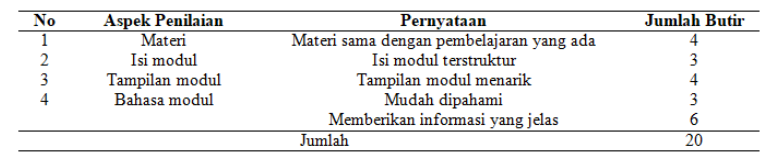

Dibawah ini merupakan tabel kisi-kisi angket untuk karakter peduli sosial siswa dengan menggunakan modul elektronik dan modul cetak. Kisi-kisi angket karakter peduli sosial digunakan sebagai pedoman penyusunan soal yang ada pada angket penelitian.

TABEL 2. Kisi-kisi angket karakter peduli social

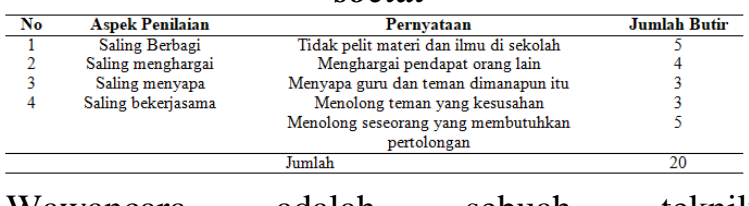

Wawancara adalah sebuah teknik mengumpulkan data-data berupa informasi dari seorang narasumber, dengan cara mengajukan 
pertanyaan serta pernyataan (Arismunandar, 2013; Rosaliza, 2015; Siregar, 2016). Wawancara yang digunakan adalah pertanyaan

TABEL 3. Kisi-Kisi Wawancara Guru

\begin{tabular}{cccc}
\hline No & Aspek penilaian & Pemyataan & Jumlah soal \\
\hline 1 & Bahan ajar cetak & Penggunaan bahan ajar modul & 6 \\
2 & Bahan ajar teknologi & Menggunakan teknologi dalam pembelajaran & 7 \\
3 & Kearifan lokal & Mengenalkan kearifan lokal kepada peserta didik & 5 \\
\hline & & Jumlah & 18 \\
\hline
\end{tabular}

Wawancara juga dilakukan dengan siswa untuk mengetahui respon peserta didik terhadap penerapan modul elektronik berbasis kearifan lokal Ngubat Padi serta modul cetak. Dengan kisi-kisi wawancara sebagai berikut:

TABEL 4. Kisi-Kisi Wawancara Siswa

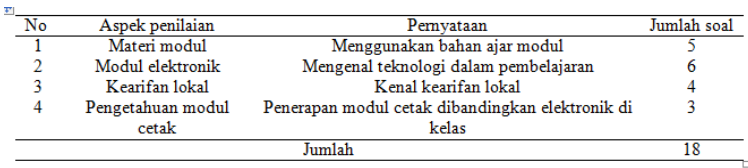

Populasi pada penelitian ini yaitu jumlah seluruh siswa kelas V di SD Negeri 64/I Muara Bulian. Sampel yang digunakan adalah seluruh siswa kelas $\mathrm{V}$ yaitu terdiri dari kelas A dan B yang berjumlah 47 siswa. Pada penentuan sampel digunakan teknik sampling yaitu sampling purposive yang teknik penentuan sampelnya dilakukan dengan pertimbangan tertentu (Sugiono, 2019). Dimana kriteria yang diterapkan oleh peneliti adalah pertimbangan keadaan sekolah serta peserta didik, sekolah yang di teliti oleh peneliti menggunakan bahan ajar cetak dan elektronik, dimana ini memudahkan data yang diperoleh peneliti dalam melihat karakter peduli sosial dengan menerapkan modul elektronik dan modul cetak.

Teknik pengumpulan data yang digunakan adalah pengumpulan data kuantitatif sebagai data utama dan diperkuat dengan data kualitatif. Data kuantitatif merupakan data yang melibatkan angka atau bilangan di dalamnya (Rofiah, Aminah \& Ekawati, 2013; Berlian, 2018; Zein, dkk, 2019). Data kuantitatif merupakan jenis data yang dapat diukur atau dihitung secara langsung. Data kuantitatif yang ada diperkuat dengan data kualitatif yang dihasilkan dari hasil wawancara. Data kualitatif adalah data dari penjelasan kata verbal tidak pertanyaan singkat, dengan jumlah soal masing 18. Adapun kisi-kisi wawancara sebagai berikut:

dapat dianalisis dalam bentuk bilangan atau angka (Gunawan, 2013; Hasanah, 2017; Rijali, 2019). Dalam penelitian, data kualitatif berupa gambaran mengenai objek penelitian. Data kualitatif memberikan dan menunjukkan kualitas objek penelitian yang dilakukan. Teknik pengumpulan data pada penelitian ini menggunakan diagram bagan alur yang dituliskan sebagai berikut :

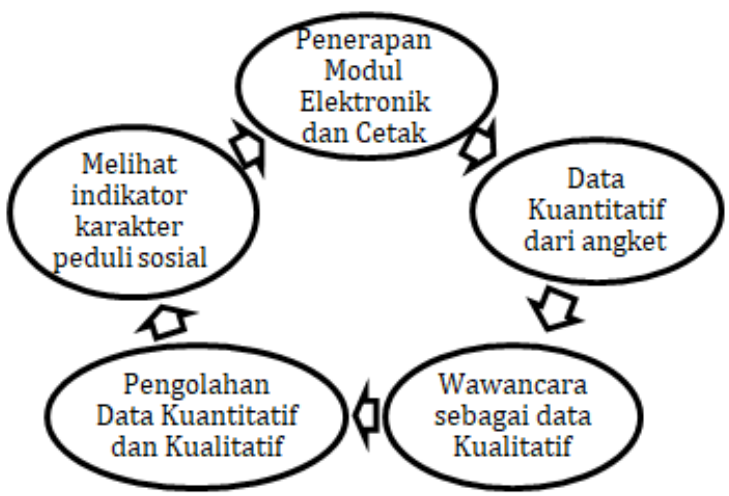

\section{Gambar 1.Bagan Alur Pengumpulan Data}

Analisis data dalam penelitian ini menggunakan statistik deskriptif dan statistik inferensial. Informasi statistik deskriptif adalah informasi statistik yang digunakan untuk menganalisis data dengan mendeskripsikan atau mendeskripsikan data yang dikumpulkan, tanpa bermaksud menarik kesimpulan yang dapat diterapkan umum atau generalisasi (Junaidi, 2014; Sari \& Wardani, 2015; Sugiono, 2019). Pada penelitian ini menggunakan statistik deskriptif dengan menggunakan nilai maksimum, minimum, mean dan standar deviasi.

Sedangkan pada statistik inferensial adalah perhitungan statistik digunakan untuk menganalisis data dari sampel dan hasilnya akan digeneralisasikan atau disimpulkan untuk populasi dari sampel itu diambil (Widiana, 2016; Sutopo \& Slamet, 2017; Kadir, 2018). Dengan menggunakan uji asumsi yaitu uji normalitas dan homogenitas, dengan mengambil hasil keputusan nilai sig pada data yang diolah. Serta menggunakan uji hipotesis yaitu uji $\mathrm{T}$ dengan ketentuan jika nilai sig < probabilitas 0,005 
maka ada pengaruh variabel bebas (X) terhadap variabel terikat $(\mathrm{Y})$ atau hipotesis diterima. Jika nilai sig > probabilitas 0,005 maka ada pengaruh variabel bebas $(\mathrm{X})$ terhadap variabel terikat $(\mathrm{Y})$ atau hipotesis ditolak.

\section{HASIL PENELITIAN}

Penerapan modul elektronik berbasis kearifan lokal Ngubat Padi dengan penerapan modul cetak pada pembelajaran dikelas ini dengan tujuan untuk melihat karakter peduli sosial siswa. Kedua bahan ajar tersebut diterapkan pada dua kelas yang berbeda dengan data yang diolah sebagai dipaparkan dibawah ini. Berikut tabel statistik deskriptif untuk respon siswa terhadap penerapan modul cetak pada karakter peduli sosial di kelas A.

Tabel 5. Respon Siswa terhadap Penerapan Modul Cetak pada Indikator Karakter Peduli Sosial Saling Berbagi di Kelas A

\begin{tabular}{|c|c|c|c|c|c|c|c|c|c|c|}
\hline \multirow{3}{*}{ Interval } & \multicolumn{3}{|l|}{ Kategori } & \multirow{3}{*}{$\begin{array}{c}\text { Tota } \\
1\end{array}$} & \multirow{3}{*}{ Mean } & \multirow{3}{*}{ Min } & \multirow{3}{*}{ Max } & \multirow{3}{*}{ Median } & \multirow{3}{*}{$\begin{array}{l}\text { Std } \\
\text { de }\end{array}$} & \multirow{3}{*}{$\%$} \\
\hline & \multirow{2}{*}{ Sikap } & \multicolumn{2}{|c|}{ Gender } & & & & & & & \\
\hline & & $f$ & $\mathbf{m}$ & & & & & & & \\
\hline $56-58$ & Sangat Tidak & 1 & - & 1 & & & & & & 3,33 \\
\hline $59-62$ & & 2 & 1 & 3 & & & & & & 10,00 \\
\hline $63-65$ & Tidak Baik & 6 & 2 & 8 & 65,8 & 56 & 71 & 64,7 & 67 & 26,66 \\
\hline $66-68$ & Cukup & 5 & 6 & 11 & & & & & & 36,66 \\
\hline $69-71$ & $\begin{array}{l}\text { Baik } \\
\text { Baik }\end{array}$ & 5 & 2 & 7 & & & & & & 23,35 \\
\hline TOTAL & & & & & & & & & & 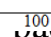 \\
\hline
\end{tabular}

kategori baik diperoleh hasil 36,66\% (11 dari 30 siswa), pada kategori cukup diperoleh hasil 26,66\% (8 dari 30 siswa) pada kategori tidak baik diperoleh hasil $10,00 \%$ (3 dari 30 siswa) dan pada kategori sangat tidak baik diperoleh hasil 3,33\% (1 orang dari 30 siswa), maka dari itu dapat dilihat bahwasanya pada penggunaan modul cetak untuk melihat karakter peduli sosial dengan indikator saling berbagi termasuk dalam kategori baik. Dimana hal ini terlihat dari data jumlah siswa yang telah mengisi angket yang berisi beberapa pertanyaan yang telah diolah peneliti dan menghasilkan data tersebut. Untuk mencapai tujuan pembelajaran siswa bekerjasama saling meminjamkan sumber belajar (buku pelajaran) kepada anggota kelompok lainnya. Seperti diharapkan peneliti pada saat penerapan modul elektronik berbasis kearifan lokal dilihat pada respon peserta didik sesuai dengan hasil pada tabel dibawah ini.

Tabel 6. Respon Siswa terhadap Penerapan Modul Elektronik Berbasis Kearifan Lokal pada Indikator Karakter Peduli Sosial Saling Bekerjasama di Kelas B

\begin{tabular}{|c|c|c|c|c|c|c|c|c|c|c|}
\hline \multirow{3}{*}{ Interval } & \multirow{3}{*}{$\begin{array}{l}\text { Kategori } \\
\text { Sikap }\end{array}$} & & & \multirow{3}{*}{$\begin{array}{c}\text { Tota } \\
1\end{array}$} & & & & & & \\
\hline & & \multicolumn{2}{|c|}{ Gender } & & \multirow[t]{2}{*}{ Mean } & \multirow[t]{2}{*}{ Min } & \multirow[t]{2}{*}{ Max } & \multirow[t]{2}{*}{ Median } & \multirow{2}{*}{$\begin{array}{c}\text { Std } \\
\text {.de } \\
\text { v }\end{array}$} & \multirow[t]{2}{*}{$\%$} \\
\hline & & f & $\mathbf{m}$ & & & & & & & \\
\hline $62-67$ & Sangat Tidak & 2 & & 2 & & & & & & 6,67 \\
\hline $68-73$ & Baik & 1 & 1 & 2 & & & & & & 13,33 \\
\hline $74-79$ & Tidak Baik & 3 & 2 & 8 & 82,0 & 62 & 91 & 83,32 & 83 & 23,33 \\
\hline $80-85$ & Cukup & 5 & 6 & 11 & & & & & & 33,33 \\
\hline $86-91$ & Baik & 5 & 2 & 7 & & & & & & 23,34 \\
\hline & Sangat Baik & & & & & & & & & \\
\hline
\end{tabular}

Penerapan modul elektronik diperoleh hasil analisis yang dilakukan oleh peneliti yaitu terdapat 23,34\% (7 dari 27 siswa) yang termasuk dalam kategori sangat baik, pada kategori baik diperoleh hasil 33,33\% (11 dari 27 siswa), pada kategori cukup diperoleh hasil 23,33\% (5 dari 27 siswa), pada kategori tidak baik diperoleh hasil 13,33\% (2 dari 27 siswa) dan pada kategori sangat tidak baik diperoleh hasil $6,67 \%$ (2 orang dari 27 siswa), maka dari itu dapat dilihat bahwasanya pada penggunaan modul elektronik untuk melihat karakter peduli sosial dengan indikator saling bekerja sama termasuk kedalam kategori baik. Hal ini terlihat dari data jumlah siswa yang telah mengisi angket yang berisi beberapa pertanyaan yang telah diolah peneliti dan menghasilkan data yang diinginkan.

\section{Uji Normalitas dan Homogenitas}

Uji normalitas dan homogenitas dilakukan pada kedua variabel yaitu penerapan modul cetak dan modul elektronik untuk melihat indikator karakter peduli sosial. Didapatkan hasil sesuai dengan tabel dibawah ini.

Tabel 7. Uji Normalitas dan Homogenitas

\begin{tabular}{ccccc}
\hline & \multicolumn{2}{c}{ Uji Normalitas } & \multicolumn{2}{c}{ Uji Homogenitas } \\
\hline Indikator & Modul Cetak & Modul Elektronik & Modul Cetak & $\begin{array}{c}\text { Modul } \\
\text { Elektronik }\end{array}$ \\
\hline Statistik & 0,256 & 0,179 & 0,424 & 0,271 \\
Df & 22 & 22 & 43 & 44 \\
sig & 0,001 & 0,064 & 0,605 & 0,519 \\
\hline
\end{tabular}

Pada tabel 3 didapat hasil uji normalitas dan homogenitas yang dilakukan di kelas IV SD Negeri 64/I Muara Bulian pada penerapan modul cetak dan modul elektronik untuk melihat indikator karakter peduli sosial. Uji normalitas dilkukan pada suatu penelitian adalah untuk mengetahui apakah data pada populasi berdistribusi normal atau sebaliknya (Rojihah, 2016). Uji normalitas dapat dikatakan normal jika nilai sig $>0,05$. Untuk menguji normalitas suatu data digunakan uji statistik Kolmogorov- 
Smirnov dengan nilai signifikansi 0,05 dengan hipotesis $\mathrm{HO}=$ sampel berasal dari populasi yang memiliki distribusi normal, $\mathrm{H} 1$ = sampel berasal dari populasi yang tidak memiliki distribusi normal. Dari data yang diolah terlihat bahwa penerapan modul elektronik berbasis kearifan lokal memiliki nilai sig diatas 0,005 sehingga dapat dikatakan normal.

Uji homogenitas dalam suatu penelitian ini menggunakan Levene's Test dari dua sampel independen (Aryani \& Mansyur, 2017). Dengan kriteria pengujian sebagai berikut: Jika nilai Levene's test atau Sig>0,05 maka variansnya homogen, sedangkan jika nilai uji Levene's $<0,05$ maka varians tidak homogen. Dari tabel diatas dapat diketahui bahwa nilai homogenitas sebesar 0,424 pada modul cetak dan 0,271 pada modul elektronik, sehingga data yang diperoleh ini dapat dikatakan homogen, karena nilai sig> 0,05 .

\section{Uji-t Sampel Independen}

Uji-t sampel independen bertujuan untuk menguji hipotesis penelitian (Amalihah, 2017). Menurut Putra \& Syarif (2014) independent t-test bertujuan untuk mengetahui apakah terdapat perbedaan yang signifikan antara kedua sampel yang diteliti. Uji-t independen dikatakan signifikan jika $\mathrm{p}<0,05$. Berikut ini adalah tabel uji-t.

Tabel 8. Uji t-test

\begin{tabular}{lll}
\hline T & Sig (2-tailed) & $\begin{array}{c}\text { Mean } \\
\text { Difference }\end{array}$ \\
\hline 9,273 & 0,002 & -18.70914 \\
7,273 & 0,002 & -18.70914 \\
\hline
\end{tabular}

Dari tabel 8 terlihat setelah dilakukan uji

t-test terlihat terdapat perbandingan penerapan modul cetak dan modul elektronik untuk melihat indikator karakter peduli sosial di kelas A dan kelas B. Hal ini menunjukkan bahwa pada penerapan modul cetak untuk melihat indikator karakter peduli sosial dengan penerapan modul elektronik untuk melihat indikator karakter peduli sosial memiliki perbandingan yang signifikan, dengan studi banding dapat dilanjutkan.

Hasil wawancara dilakukan terhadap siswa untuk menunjukkan karakter peduli sosial terhadap lingkungan sosialnya. Pada penelitian ini ada dua dimensi pengukuran karakteryang dilakukan yaitu implikasi sosial dari sikap peserta didik di lingkungan kelas dan sikap peserta didik di lakukan di luar lingkungan kelas. Pada saat di kelas dengan diterapkannya modul elektronik siswa merasa senang dan bersemangat dalam belajar dibandingkan dengan menggunakan bahan ajar cetak. Mereka lebih aktif dalam belajar serta raa ingin tahu mereka tinggi. Selanjutnya hasil wawancara dilakukan kepada guru sebagai pendidik untuk mengetahui pengatahuan serta kemampuan guru menerapkan bahan ajar baik itu elektronik maupun bahan ajar cetak. Guru mengungkapkan bahwa mengalami kesulitan pada tahap pengoperasian bahan ajar elektronik, mereka lebih memilih menggunakan bahan ajar cetak yang biasa mereka gunakan sebelumnya. Namun ada kemauan untuk belajar mengoperasikan serta menerapkan bahan ajar elektronik di kelas.

\section{PEMBAHASAN}

Penerapan bahan ajar atau modul berbasis elektronik ataupun modul cetak di kelas V (A \& B) SD Negeri 64/I Muara Bulian mendapatkan hasil yaitu saat penerapan modul cetak dan elektronik dapat dilihat respon siswa baik. Hal ini dikarenakan pembelajaran menggunakan modul cetak tidak bervariasi dan lebih membosankan. Sedangkan saat penerapan modul elektronik siswa lebih bersemangat dalam mengikuti pembelajaran. Penerapan modul cetak dapat dilihat karakter peduli sosial yang terbentuk itu lebih sedikit dampaknya dibandingkan dengan saat penerapan modul elektronik. Pada kelas A dengan penerapan modul elektronik dengan nilai

Perbedaan ini dikarenakan

Data hasil analisis uji asumsi dan uji hipotesis menunjukkan data yang dihasilkan sudah homogen dan normal dilihat dari data yang menunjukkan nilai yang signifikan. Uji homogenitas dalam suatu penelitian ini menggunakan Levene's Test dari dua sampel independen (Aryani \& Mansyur, 2017). Dengan kriteria pengujian sebagai berikut: Jika nilai Levene's test atau Sig> 0,05 maka variansnya homogen, sedangkan jika nilai uji Levene's $<0,05$ maka varians tidak homogen. Dari tabel diatas dapat diketahui bahwa nilai homogenitas sebesar 0,424 pada modul cetak dan 0,271 pada modul elektronik, sehingga data yang diperoleh 
ini dapat dikatakan homogen, karena nilai sig> 0,05 . Uji normalitas dan uji homogenitas menjadi sangat penting dipenuhi karena pada asumsi awal suatu persamaan regresi linear dikatakan baik jika galat regresi berdistribusi normal dan homogen (Sukestiyarno \& Agoestanto, 2017). Sedangkan uji hipotesisnya dilihat dari tabel uji-t dilakukan utnuk melihat hipotesis yang diajukan sudah dapat diterima atau tidak. Pada analisis uji-t yang telah dilakukan hipotesis yang diajukan sudah dapat diterima dengan baik dapat dilihat pada tabel yang ada bahwasannya nilai sig sudah kurang dari 0,05 .

Sesuai dengan penelitian sebelumnya yang dlakukan Akhyar, dkk, 2017; Darvina \& Tiffani, 2019; Marlia, Saripudin \& Kasmansyah, 2021) yang menerapkan modul berbasis elektronik untuk melihat karakter peduli sosial peserta didik. Penelitian yang dilakukan menilai penerapan modul elektronik dianggap lebih praktis dan efesien jika harus menggunakan buku pembelajaran atau tema. Penggunaan modul elektronik sangat efektif untuk meningkatkan motivasi belajar siswa, disamping itu efektif juga untuk meningkatkan hasil belajar siswa, serta kemampuan berpikir kritis (Nurhidayati, Putro \& Widiyaningtyas, 2018). Oleh karena itu penerapan modul elektronik dianggap lebih baik daripada modul cetak karena selain praktis, efektif, dan meningkatkan motivasi belajar siswa modul elektronik juga dapat meningkatkan hasil belajar jauh lebih baik dibandingkan dengan menggunakan modul cetak karena dapat meningkatkan tingkat berpikir kritis siswa.

Implikasi dari penelitian perbandingan respon peserta didik pada dua kelas berbeda dengan menerapkan modul elektronik berbasis kearifan lokal dalam pembelajaran kelas $\mathrm{V}$ pada Tema 8 dan Subtema 1 pembelajaran 3 dalam mencari tahu keberagaman kearifan lokal di Provinsi setempat tepatnya Provinsi Jambi. Selain itu menjadi bahan ajar yang sesuai dengan kebutuhan siswa dan bisa digunakan sebagai sumber belajar mandiri. Selain itu, guru dapat menggunakan modul elektronik sebagai alat penghubung serta perantara dalam menyampaikan materi yang tidak terdapat dalam kurikulum yang berlaku, namun perlu diajarkan kepada peserta didik. Keterbatasan Penelitian ini yaitu modul elektronik ini terbatas pada kompetensi dasar kelas $\mathrm{V}$ tema 8 subtema 3 pembelajaran 3 yang berbasis kearifan lokal Ngubat Padi. Rekomendasi penelitian ini penerapan modul elektronik berbasis kearifan lokal Ngubat Padi dapat diterapkan pada karakter peduli lingkungan, peduli sosial, dan disiplin.

Keterbaruan pada penelitian ini adalah pada variabel yang diteliti yaitu indikator karakter peduli sosial. Indikator tersebut dilihat setelah penerapan modul elektronik serta modul cetak pada kelas yang berbeda pada penelitian ini untuk melihat perbandingan dari penerapan modul elektronik dengan modul cetak dengan indikator karakter peduli sosial. Sedangkan pada penelitian sebelumnya banyak meneliti keterhubungan dengan karakter peduli sosial tidak pada indikator karakternya.

\section{KESIMPULAN}

Berdasarkan hasil yang telah diuraikan, ditemukan bahwa dari dua bahan ajar yang diterapkan yakni modul cetak dan modul elektronik dapat melihat indikator karakter peduli sosial. Pada penelitian hasil dominan baik untuk melihat indikator karakter peduli sosial dengan penerapan modul elektronik, sedangkan untuk penerapan modul cetak pada kategori cukup baik, dari hal tersebut terlihat terdapat perbedaan diantara kedua bahan ajar yang diterpakan untuk melihat indikator karakter peduli sosial, hal ini diperkuat dengan hasil uji t yang telah dilakukan, dimana sig yang diperoleh lebih kecil dari 0,05 maka terdapat perbedaan diantara keduanya.

\section{DAFTAR PUSTAKA}

Abdurahimovna, U. F. (2020). Advantages of using electronic learning resources in the educational process. European Journal of Research and Reflection in Educational Sciences Vol, 8(8).

Afriandi, M. R., Elmunsyah, H., \& Putranto, H. (2020). Pengembangan Bahan Ajar Cetak Mata Pelajaran Instalasi Motor Listrik Bermuatan Peta Konsep Untuk Menumbuhkan Pemahaman Konsep Belajar Pada Siswa SMK Kelas XI 
Jurusan TITL. Jurnal Pendidikan Teknik Elektro Undiksha, 9(2), 64-71.

Akhyar, A., Zamzami, Z., Syamsul, S., \& Zulkarnain, Z. (2017). PEMBUATAN MODUL LABORATORIUM BERBASIS MIKROKONTROLER DENGAN MEMANFAATKAN LIMBAH KOMPONEN ELEKTRONIKA. In Prosiding Seminar Nasional Politeknik Negeri Lhokseumawe (Vol. 1, No. 1, pp. 5-7).

Ambarita, J. (2021). Workshop Pembuatan EBook Sebagai Bahan Ajar Elektronik Interaktif Untuk Guru Indonesia Secara Online Di Tengah Covid 19. Community Engagement and Emergence Journal (CEEJ), 2(1), 44-57.

Amelia, D. J. (2018). Pengembangan Bahan Ajar Cetak Dalam Bentuk Komik Untuk Siswa Kelas III Sekolah Dasar. Jurnal Pemikiran dan Pengembangan Sekolah Dasar (JP2SD), 6(2), 136-143.

Arismunandar, S. (2013). Teknik Wawancara Jurnalistik. Teknik Wawancara Jurnalistik.

Aryani, W., \& Mansur (2017). Penggunaan Alat Peraga Mistar Hitung Terhadap Hasil Belajar Siswa Pokok Bahasan Penjumlahan Dan PenguranganBilangan $\mathrm{Bu}$ lat. Utama: Jurnal Keilmuan dan Kependidikan Dasar, 9(1), 55-78.

Aulia, N., \& Wuryandani, W. (2019). Multicultural strip comic as a learning media to improve the caring character in primary school. Journal of Education and Learning (EduLearn), 13(4), 527-533.

Barlian, E. (2018). Metodologi Penelitian Kualitatif \& Kuantitatif.

Basri, I. (2017). Evaluasi Pembelajaran Sekolah Dasar (SD) Berbasis Pendidikan Karakter dan Multikultural. Jurnal Ilmiah Sekolah Dasar, 1(4), 247-251.

Busyaeri, A., \& Muharom, M. (2016). Pengaruh sikap guru terhadap pengembangan karakter (peduli sosial) siswa di MI Madinatunnajah Kota Cirebon. Al Ibtida: Jurnal Pendidikan Guru MI, 2(1).

Cahyadi, R. A. H. (2019). Pengembangan Bahan Ajar Berbasis ADDIE Model. Halaqa: Islamic Education Journal, 3(1), 35-42.
Creswell, J. W. (2013). Steps in conducting a scholarly mixed methods study.

Damayanti, P. S. (2020). Analisis Keintegrasian Muatan Pelajaran Sekolah Dasar Kelas III Tema Energi dan Perubahannya Dalam Implementasi Kurikulum 2013. PENDASI: Jurnal Pendidikan Dasar Indonesia, 4(2), 12-22.

Darvina, Y., \& Tiffani, D. (2019, July). Efektivitas Modul Elektronik Interaktif Fisika Dengan Pendekatan Saintifik dan Bermuatan Nilai Karakter dalam Meningkatkan Kompetensi Siswa Kelas X SMA. In Talenta Conference Series: Science and Technology (ST) (Vol. 2, No. 2).

Davidson, J. C., Milligan, I., Quinn, N., Cantwell, N., \& Elsley, S. (2016). Developing family-based care: complexities in implementing the UN Guidelines for the Alternative Care of Children. European Journal of Social Work, 20(5), 754-769.

Deane, A. (2020). SELF-MOTIVATION AND STAFF LEARNING. Journal of Character Education: Vol. 16\# 2, 16(2), 49.

Dyrvold, A., \& Bergvall, I. (2018). Multimodal resources in school mathematics and their potential to express meaning in digital and printed teaching materials. In ECER, 4-7 September, 2018, Bolzano, Italy.

Eko, S. (2020). Local Wisdom: Pillar Development of Multicultural Nations and National Education Values. Cypriot Journal of Educational Sciences, 15(6), 1587-1598.

Eliza, D. (2017). Pengembangan Model Pembelajaran Karakter Berbasis Cerita Tradisional Minangkabau Untuk Anak Usia Dini. Pedagogi: Jurnal Anak Usia Dini dan Pendidikan Anak Usia Dini, $3(3 b)$.

Farida, I., \& Yani, D. E. (2013). Analisis kualitas dan tingkat keterbacaan materi bahan ajar cetak melalui evaluasi formatif. Jurnal Pendidikan Terbuka Dan Jarak Jauh, 14(2), 79-87.

Fauzi, A., Zainuddin, Z., \& Atok, R. (2018). Penguatan karakter rasa ingin tahu dan 
peduli sosial melalui discovery learning. Jurnal Teori dan Praksis Pembelajaran IPS, 2(2), 83-93.

Ghufron, A. (2017). Pengembangan Pembelajaran Berbasis Nilai-Nilai Budaya Yogyakarta Di Sekolah Dasar. Cakrawala Pendidikan, (2), 81677.

Gunawan, I. (2013). Metode penelitian kualitatif. Jakarta: Bumi Aksara, 143.

Gunawan, I., Benty, D. D. N., Kusumaningrum, D. E., Sumarsono, R. B., Sari, D. N., Pratiwi, F. D., ... \& Hui, L. K. (2019). Validitas dan Reliabilitas Angket Keterampilan Manajerial Mahasiswa. JAMP: Jurnal Administrasi dan Manajemen Pendidikan, 2(4), 247-257.

Hasanah, H. (2017). Teknik-teknik observasi (sebuah alternatif metode pengumpulan data kualitatif ilmu-ilmu sosial). AtTaqaddum, 8(1), 21-46.

Hermawan, I. (2019). Metodologi Penelitian Pendidikan (Kualitatif, Kuantitatif dan Mixed Method). Hidayatul Quran.

Hinojosa, J., Viviente, F. L. M., Hernández, V. G., \& Merino, R. R. (2020). Teachinglearning model for the science of electronics. JOTSE, 10(1), 87-100.

Junaidi, J. (2014). Statistika Deskriptif dengan Microsoft Excel.

Kadir, A. (2018). Pengaruh Kompetensi Dosen Dan Motivasi Belajar Terhadap Kemampuan Analisis Statistika Mahasiswa Ftik IAIN Kendari. Al-Izzah: Jurnal Hasil-Hasil Penelitian, 13(1), 115.

Kazu, I. Y., \& Is, A. (2018). An Investigation about Actualization Levels of Learning Outcomes in Early Childhood Curriculum. Journal of Education and Training Studies, 6(3), 66-77.

Kurniawan, D. A., Novianti, U., \& Parhati, L. N. (2020). Local Account Analysis that can be Integrated into the Basic IPS Competence in Class VI Basic School. Journal of Educational and Social Research, 10(5), 66-66.

Kurniawan, M. I. (2013). Integrasi Pendidikan Karakter Ke Dalam Pembelajaran Kewarganegaraan Di Sekolah Dasar.
Jurnal Pemikiran dan Pengembangan Sekolah Dasar (JP2SD), 1(1), 37-45.

Kurniawati, F. E., \& Miftah, M. (2015). Pengembangan bahan ajar aqidah ahklak di madrasah ibtidaiyah. Jurnal Penelitian, 9(2), 367-388.

Lawe, Y. U., Noge, M. D., Wede, E., \& Itu, I. M. (2021). PENGGUNAAN BAHAN AJAR ELEKTRONIK MULTIMEDIA BERBASIS BUDAYA LOKAL PADA TEMA DAERAH TEMPAT TINGGALKU UNTUK MENINGKATKAN KEMAMPUAN BERPIKIR TINGKAT TINGGI SISWA SEKOLAH DASAR. Jurnal Ilmiah Pendidikan Citra Bakti, 8(1), 92-102.

Lestari, S., \& Rohani, R. (2017). Penanaman Karakter peduli sosial di Sekolah Menengah Pertama Negeri 1 Tangaran Kabupaten Sambas. Jurnal Pendidikan Kewarganegaraan, 1(2).

Li, L., Worch, E., Zhou, Y., \& Aguiton, R. (2015). How and why digital generation teachers use technology in the classroom: An explanatory sequential mixed methods study. International Journal for the Scholarship of Teaching and Learning, 9(2), n2.

Lim, K. H. A., Loo, Z. Y., Goldie, S. J., Adams, J. W., \& McMenamin, P. G. (2016). Use of 3D printed models in medical education: a randomized control trial comparing 3D prints versus cadaveric materials for learning external cardiac anatomy. Anatomical sciences education, 9(3), 213-221.

Lioufas, P. A., Quayle, M. R., Leong, J. C., \& McMenamin, P. G. (2016). 3D printed models of cleft palate pathology for surgical education. Plastic and Reconstructive Surgery Global Open, 4(9).

MARLIA, R., Saripudin, A., \& Kasmansyah, K. (2021). PENGEMBANGAN MODUL ELEKTRONIK (E-MODUL) BERBASIS 3D PAGEFLIP PROFESSIONAL DALAM PEMBELAJARAN KETERAMPILAN MENULIS PUISI SISWA KELAS X MAN 1 PRABUMULIH 
(Doctoral dissertation, Sriwijaya University).

Maryuliana, M., Subroto, I. M. I., \& Haviana, S. F. C. (2016). Sistem informasi angket pengukuran skala kebutuhan materi pembelajaran tambahan sebagai pendukung pengambilan keputusan di sekolah menengah atas menggunakan skala likert. TRANSISTOR Elektro dan Informatika, 1(1), 1-12.

Muhamadi, S., \& Hasanah, A. (2019). Penguatan Pendidikan Karakter Peduli Sesama Melalui Kegiatan Ekstrakurikuler Relawan. Jurnal Pendidikan Agama Islam, 16(1), 95-114.

Mumpuni, K. E. (2013, October). Potensi pendidikan keunggulan lokal berbasis karakter dalam pembelajaran biologi di indonesia. In Prosiding Seminar Biologi (Vol. 10, No. 2).

Muqodas, R. Z., Sumardi, K., \& Berman, E. T. (2015). Desain dan pembuatan bahan ajar berdasarkan pendekatan saintifik pada mata pelajaran sistem dan instalasi refrigenerasi. Jurnal of Mechanical Engineering, 2(1), 108.

Murniyetti, M., Engkizar, E., \& Anwar, F. (2016). Pola pelaksanaan pendidikan karakter terhadap siswa sekolah dasar. Jurnal Pendidikan Karakter, 6(2).

Naryatmojo, D. L. (2019). Internalization the Concept of Local Wisdom for Students in the Listening Class. Arab World English Journal (AWEJ) Volume, 10.

Noviyanita, W. (2019). PENGEMBANGAN BAHAN AJAR ELEKTRONIK BERBASIS FLIPBOOK MAKER PADA MATERI PROGRAM LINEAR KELAS X SMK. Delta: Jurnal Ilmiah Pendidikan Matematika, 6(2), 41-49.

Nuraini, L. (2019). Integrasi Nilai Kearifan Lokal dalam Pembelajaran Matematika SD/MI Kurikulum 2013. Jurnal Pendidikan Matematika (Kudus), 1(2).

Nurhidayati, A., Putro, S. C., \& Widiyaningtyas, T. (2018). Penerapan model PBL berbantuan e-modul berbasis flipbook dibandingkan berbantuan bahan ajar cetak pengaruhnya terhadap hasil belajar pemrograman siswa SMK. Teknologi dan
Kejuruan: Jurnal Teknologi, Kejuruan, dan Pengajarannya, 41(2), 130-138.

Nuryati, N., Anggoro, B. S., \& Putra, R. W. Y. (2021). PENGEMBANGAN BAHAN AJAR ELEKTRONIK BILANGAN BULAT DAN PECAHAN BERBASIS ALQURUN TEACHING MODEL. $A L$ KHAWARIZMI: Jurnal Pendidikan Matematika, 1(1), 50-59.

Pradana, J., Khoirunnisa, F., \& Yulita, I. (2020). ANALISIS KEBUTUHAN SISWA DAN GURU DALAM PENGEMBANGAN BAHAN AJAR PADA MATERI LARUTAN ASAM BASA DI SMA NEGERI 2 TANJUNGPINANG. Student Online Journal (SOJ) UMRAH-Keguruan dan Ilmu Pendidikan, 1(2), 495-499.

Puspitasari, A. D. (2019). Penerapan Media Pembelajaran Fisika Menggunakan Modul Cetak dan Modul Elektronik pada Siswa SMA. Jurnal Pendidikan Fisika, 7(1), 17-25.

Qodariah, L., \& Armiyati, L. (2013). Nilai-Nilai kearifan lokal masyarakat adat Kampung Naga sebagai alternatif sumber belajar. SOCIA: Jurnal Ilmu-Ilmu Sosial, 10(1).

Rahmawati, S., \& Dewi, N. K. (2020). Dampak media pembelajaran kisah keteladanan terhadap karakter peduli sosial dan prestasi belajar anak sekolah dasar. Jurnal Civics: Media Kajian Kewarganegaraan, 17(2), 153-163.

Ramdani, E. (2018). Model pembelajaran kontekstual berbasis kearifan lokal sebagai penguatan pendidikan karakter. JUPIIS: Jurnal Pendidikan Ilmu-Ilmu Sosial, 10(1), 1-10.

Rijali, A. (2019). Analisis data kualitatif. Alhadharah: Jurnal Ilmu Dakwah, 17(33), 81-95.

Roessingh, H. (2020). Culturally Responsive Pedagogy and Academic Vocabulary Teaching and Learning: An Integrated Approach in the Elementary Classroom. TESL Canada Journal, 37(1), 51-62.

Rofiah, E., Aminah, N. S., \& Ekawati, E. Y. (2013). Penyusunan Instrumen tes kemampuan berpikir tingkat tinggi fisika pada siswa SMP. Jurnal pendidikan fisika, l(2). 
Rosaliza, M. (2015). Wawancara, Sebuah interaksi komunikasi dalam penelitian kualitatif. Jurnal Ilmu Budaya, 11(2), 7179.

Sahin, A. E., \& Is Guzel, C. (2018). Investigation of School Readiness and Academic Development of Elementary Students Firstly Enrolled at School with'4+ 4+ 4 Education Regulation'in Turkey. Educational Policy Analysis and Strategic Research, 13(2), 104-127.

Saputro, H. B., \& Soeharto, S. (2015). Pengembangan media komik berbasis pendidikan karakter pada pembelajaran tematik-integratif kelas IV SD. Jurnal Prima Edukasia, 3(1), 61-72.

Sari, N., \& Wardani, R. (2015). Pengolahan dan Analisis Data Statistika dengan SPSS. Deepublish.

Satriawan, M., \& Rosmiati, R. (2017). Pengembangan bahan ajar fisika berbasis kontekstual dengan mengintegrasikan kearifan lokal untuk meningkatkan pemahaman konsep fisika pada mahasiswa. JPPS (Jurnal Penelitian Pendidikan Sains), 6(1), 1212-1217.

Senjaya, A. J. (2018). Tinjauan Kritis Terhadap Istilah Metode Campuran (Mixed Method) dalam Riset Sosial. Risâlah, Jurnal Pendidikan dan Studi Islam, 4(1, March), 103-118.

Seso, M. A., Laksana, D. N. L., \& Dua, K. (2019). Pengembangan Bahan Ajar Elektronik Bermuatan Multimedia Untuk Siswa Sekolah Dasar Kelas Iv Di Kabupaten Ngada. Journal of Education Technology, 2(4), 177-185.

Setiawan, A., \& Sulistiani, I. R. (2019). Pendidikan Nilai, Budaya Dan Karakter Dalam Pembelajaran Matematika Dasar Pada SD/MI. Elementeris: Jurnal Ilmiah Pendidikan Dasar Islam, 1(1), 41-56.

Shufa, N. K. F. (2018). Pembelajaran Berbasis Kearifan Lokal Di Sekolah Dasar: Sebuah Kerangka Konseptual. INOPENDAS: Jurnal Ilmiah Kependidikan, 1(1).

Siregar, N. (2016). Meninjau Kemampuan Penalaran Matematis Siswa SMP melalui Wawancara Berbasis Tugas Geometri.
Mosharafa: Jurnal Pendidikan Matematika, 5(2), 128-137.

Skoufaki, S., \& Petrić, B. (2021). Academic vocabulary in an EAP course: Opportunities for incidental learning from printed teaching materials developed inhouse. English for Specific Purposes, 63, 71-85.

Sokolova, E., Rostovtseva, V., \& Wasilewski, M. (2015). The advantages of the network-based electronic teaching package by the implementation of English for specific purposes course. ProcediaSocial and Behavioral Sciences, 206, 193198.

Sopacua, J., Fadli, M. R., \& Rochmat, S. (2020). The History Learning Module Integrated Character Values. Journal of Education and Learning (EduLearn), 14(3), 463472.

Sudibyo, E., Jatmiko, B., \& Widodo, W. (2017). Pengembangan instrumen motivasi belajar fisika: angket. Jurnal Penelitian Pendidikan IPA, 1(1), 13-21.

Sugiono. 2019. Metode Penelitian Kuantitatif, Kualitatif dan $\mathrm{R}$ \& $\mathrm{D}$. Bandung : Alfabeta.

Sukestiyarno, Y. L., \& Agoestanto, A. (2017). Batasan Prasyarat Uji Normalitas Dan Uji Homogenitas Pada Model Regresi Linear. Unnes Journal of Mathematics, 6(2), 168-177.

Suwatra, W., \& Suyatna, A. (2015, October). Bahan Ajar Elektronik Global Warming Berbasis Inkuiri dengan Pendekatan Keterampilan Berfikir Kritis. In Prosiding Seminar Nasional Fisika (E-Journal) (Vol. 4, pp. SNF2015-II).

Tarfaoui, M., Nachtane, M., Goda, I., Qureshi, Y., \& Benyahia, H. (2020). 3D printing to support the shortage in personal protective equipment caused by COVID19 pandemic. Materials, 13(15), 3339.

Ufie, A. (2014). Mengintegrasikan Nilai-Nilai Multikulturalisme Berbasis Kearifan Lokal Sebagai Sumber Pembelajaran Sejarah. Jurnal Criksetra, 3(2), 47-61.

Utari, U., \& Degeng, I. N. S. (2017). Pembelajaran tematik berbasis kearifan lokal di sekolah dasar dalam menghadapi 
Masyarakat Ekonomi Asean (MEA). Jurnal Teori dan Praksis Pembelajaran IPS, 1(1), 39-44.

Wariin, I. (2014). Nilai-nilai Kearifan Lokal (Local Wisdom) Tradisi Memitu pada Masyarakat Cirebon Studi Masyarakat Desa Setupatok Kecamatan Mundu. Edunomic Jurnal Pendidikan Ekonomi, 2(1).

Wentas, R. (2019). PENDIDIKAN AGAMA HINDU BERBASIS BUDAYA DALAM MEMBENTUK KARAKTER PESERTA DIDIK. Bawi Ayah: Jurnal Pendidikan Agama Dan Budaya Hindu, 10(1), 66-82.

Widiana, I. W. (2016). E-Modul Berorientasi Pemecahan Masalah Dalam Pembelajaran Statistik Inferensial. Prosiding Semnas Hasil Penelitian.

Winarni, E. W., Purwandari, E. P., Lusa, H., \& Dadi, S. (2018). The Impact of Thematic Learning Integrated ICT in Tabot Bengkulu as Cultural Ceremony toward Social Interaction Knowledge in Elementary School. Asian Journal of Education and Training, 4(2), 70-74.

Wipulanusat, W., Panuwatwanich, K., Stewart, R. A., \& Sunkpho, J. (2020). Applying mixed methods sequential explanatory design to innovation management. In The 10th International Conference on
Engineering, Project, and Production Management (pp. 485-495). Springer, Singapore.

Wisdom, S. C. (2018). Teachers' Perceptions About the Influence of High-Stakes Testing on Students.

Wuryandani, W., Maftuh, B., \& Budimansyah, D. (2014). Pendidikan Karakter Disiplin di Sekolah Dasar. Jurnal Cakrawala Pendidikan, 33(2).

Yulianti, S. D., Djatmika, E. T., \& Santoso, A. (2017). Pendidikan karakter kerja sama dalam pembelajaran siswa sekolah dasar pada kurikulum 2013. Jurnal teori dan praksis pembelajaran IPS, 1(1), 33-38.

Yuliati, L. (2013). Efektivitas bahan ajar IPA terpadu terhadap kemampuan berpikir tingkat tinggi siswa SMP. Jurnal Pendidikan Fisika Indonesia, 9(1).

Zein, S. Z., Yasyifa, L. Y., Ghozi, R. G., Harahap, E., Badruzzaman, F. H., \& Darmawan, D. (2019). Pengolahan dan Analisis Data Kuantitatif Menggunakan Aplikasi SPSS. Teknologi Pembelajaran, 4(2).

Zuriah, N., Sunaryo, H., \& Yusuf, N. (2016). IbM guru dalam pengembangan bahan ajar kreatif inovatif berbasis potensi lokal. Jurnal Dedikasi, 13. 